SECTION 21. Pedagogy. Psychology. Innovations in the field of education.

Sholpan Erlepesovna Zhysipbekova senior teacher Kazakh National Medical University named after S. D.Asfendiyarov, Kazakhstan sholpan_80aeka@mail.ru

Shynar Abubakirovna Zhakipova teacher

Kazakh National Medical University named after S. D.Asfendiyarov, Kazakhstan shinar85@mail.ru

Aliya Sharizatovna Barakova teacher

Kazakh National Medical University named after S. D.Asfendiyarov, Kazakhstan balia79@mail.ru

УДК 681.142.37:681.142:377

\title{
APPLICATION OF BLOCK TECHNOLOGIES FOR FORMATION OF THE EDUCATIONAL INFORMATIVE COMPETENCES AT INFORMATICS LESSONS
}

Abstract: The block method can be used for increase of creative activity of students in educational and informative activity, for development and realization of their potential opportunities. The method contains opportunities for identification, training and education of students, promotes achievement of stable results of training.

Key words: block method, training, education.

\section{ПРИМЕНЕНИЕ БЛОЧНЫХ ТЕХНОЛОГИЙ ДЛЯ ФОРМИРОВАНИЯ УЧЕБНО- ПОЗНАВАТЕЛЬНОЙ КОМПЕТЕНЦИИ НА УРОКАХ ИНФОРМАТИКИ}

Аннотация: Блочный метод можно использовать для повышения творческой активности студентов в учебно-познавательной деятельности, для развития и реализачии их потенциальных возможностей. Метод содержит возможности по выявлению, обучению $u$ воспитанию студентов, способствует достижению стабильных результатов обучения.

Ключевые слова: блочный метод, обучение, воспитание.

Educational activity, as well as any other, is defined by the motives expressed through informative interest. If the student has an interest to a subject, motives to training develop also.

The motivation of actions and acts which is directed on is necessary for the organization of informative activity [1-9]:

- ensuring understanding of value of acquired knowledge, abilities, experience of creative activity;

- conscientious attitude to their assimilation;

- emotional lifting;

- formation of informative interests.

It is necessary that students were able to get knowledge independently, finding thus at first ways of their receiving.

Training methods also influence motives of the doctrine. Therefore, having carried out research activity - improvement of teaching of informatics, we came to a conclusion about 
efficiency use of block technologies for formation of educational and informative competence of the being trained.

Process of application of block technologies at assimilation of discipline of "Information scientist" consists of several stages.

At the I stage (statement of an educational task) efforts are directed on motivation creation:

1) Explanation to students of practical value of knowledge of informatics, their role in an everyday life of each person.

2) Acquaintance of students with professions for which knowledge of informatics is necessary.

3) Drawing attention of students to the unusual facts, processes.

4) Message to students of important historic facts.

5) The big role motivations is played by the organization of educational activity with various sources of information: textbooks, directories, Internet. All this material security promotes development of memory, thinking, imagination, speech.

6) One more direction of creation of motivation - increase in informative capacity of discipline. To students it is reported about communication of separate subjects among themselves, the practical importance and a role of new knowledge in a complete picture of discipline.

7) A certain role motivations is played by an assessment of educational activity of students. At lessons are used different ways of control of results of training: offsets on subjects, testing of the different contents, mutual testing, self-examination, oral and written frontal polls...

At the II stage (opening of new knowledge) the problem which was put at the previous stage is solved. Lectures, dialogue with students, collective supervision, small research works are for this purpose used.

During primary fixing (the III stage) during practical works on the computer there is an assimilation of new concepts. There are used different types of tasks for comparison of theoretical knowledge and practical tasks which allow to transfer new knowledge from level of external speech on computer language.

The choice of a form, method and type of work for fixing depends on degree of understanding of a new material. It is necessary to prepare some options of tasks, to be reconstructed at a lesson.

At a stage of independent work (the IV stage) three didactic problems are solved:

1) definition of difficulties in assimilation of the new;

2) identification of extent of assimilation new;

3) self-checking and self-assessment students of the work.

Independent work of students is directed on the solution of tasks with application of a new material in the standard and combined situations. They are shown in the form of computer tasks.

After performance of independent work to the student questions for a result assessment are set, and is discussed those questions which remained not understood. Then mistakes are again corrected. It is important that at this stage for each student the success situation ("I was created I can, at me it turns out! "), also there was a desire to consolidate successful result.

At the last stage (the V stage) total control of knowledge of students which passes in a look tests of students on materials of all semester is exercised.

The block method can be used for increase of creative activity of students in educational and informative activity, for development and realization of their potential opportunities. The method contains opportunities for identification, training and education of students, promotes achievement of stable results of training. 
And in the conclusion there is a wish to tell that that method which you use at lessons, and productivity as an indicator of quality of work is important not.

\section{References:}

1. Guzeev, V.V. Scheduling of results of education and educational technology/century V. Guzeev. - M, National education, 2001.

2. Guzeev, V.V. Methods and organizational forms of Education/century V. Guzeev. - M, National education, 2001.

3. Levitas, G.G. Technology of educational cycles/@ Levitas.-M: Ileksa, 2002.

4. McKenzie, J. (2000). Beyond technology: Questioning, research and the information literate school. Bellingham, WA: FNO Press.

5. Golovan' M. Informatichna kompetentnist': sutnist', struktura i stanovlennja. // Informatika ta informacijni texnologiji v navchal'nix zakladax. - 2007.- № 4. - s.62 - 69.

6. Burmakina V. F., Zelman, M., Falina, I. N.. Bol'shaja Semyorka (B7). Informacionnokommunikacionno-texnologicheskaja kompetentnost'. Metodicheskoe rukovodstvo dlja podgotovki $\mathrm{k}$ testirovaniju uchitelej. Mezhdunarodnyj bank rekonstrukcii i razvitija. Nacional'nyj fond podgotovki kadrov. Centr razvitija obrazovanija ANX pri pravitel'stve RF, Moskva, 2007. - http://ifap.ru/library/book360.pdf .

7. Anisfeld, M. (1987). A course to develop competence in critical reading of empirical research in psychology. Teaching of Psychology, 14, 224-227.

8. Baker, L. \& Brown, A. (1984). Cognitive monitoring in reading. In J. Flood (Ed.), Understanding Reading Comprehension. Newark, DE: International Reading Association.

9. Collins, N. \& Smith, C. (1990). Role of metacognition in reading to learn. (ERIC Document Reproduction Service No. ED 333-386) 